\title{
Perceived (In)justice of Public Land Acquisition
}

\author{
S. M. Holtslag-Broekhof ${ }^{1,2} \cdot$ R. van Marwijk ${ }^{2}$. \\ R. Beunen ${ }^{3}$ J. S. C. Wiskerke ${ }^{1}$
}

Accepted: 10 December 2015/Published online: 24 December 2015

(C) The Author(s) 2015. This article is published with open access at Springerlink.com

\begin{abstract}
Many studies have addressed the justice of public land acquisition, but few studies have addressed the question of what landowners perceive as just. Individual perceptions drive an important part of the social and scientific debates on legitimate and just land acquisition. This article addresses this gap by studying landowners' and land purchasers' perceptions of just land acquisition. We did this by uncovering the prevailing discourse on just land acquisition and studying the values that shaped people's perceptions of just land acquisition. The results showed that perceptions of justice are based on the values of lawfulness, decentness and equality. These values were translated into different norms that resulted in expectations pertaining to just land acquisition. Insight into the different perceptions and the prevailing discourse of just land acquisition and their underlying values increases the understanding of land acquisition processes and land policy strategies. First, it becomes apparent that land acquisition has an essential element of injustice that cannot be avoided by a good process or a just compensation fee. Second, insight in different discourses provides valuable input for debates on just land acquisition. Third, such insight shows that money is not always a sufficient means of
\end{abstract}

S. M. Holtslag-Broekhof

Sanne.broekhof@wur.nl

R. van Marwijk

Ramona.vanmarwijk@kadaster.nl

R. Beunen

Raoul.beunen@ou.nl

J. S. C. Wiskerke

han.wiskerke@wur.nl

1 Rural Sociology Group, Wageningen University, P.O. Box: 8130, 6700 EW Wageningen, The Netherlands

2 The Netherlands' Cadastre, Land Registry and Mapping Agency, Apeldoorn, The Netherlands

3 Open University, Heerlen, The Netherlands 
indemnification. The combination of sufficient financial compensation, the opportunity of a new location, attractive selling conditions and accurate and open process are all important requisites to ensure that public land acquisition is perceived by the majority of landowners as just.

Keywords Perceived justice $\cdot$ Land acquisition $\cdot$ Landowners $\cdot$ Land purchasers

\section{Introduction}

Land acquisition by governments has been the topic of many debates on legitimacy and justice (Moyo 2000; Larbi et al. 2004; Morris 2007; Sarkar 2007). Justice has been an important starting point and prerequisite ${ }^{1}$ for most expropriation laws. Social and scientific debates on the justice of expropriation and public land acquisition revolve mainly around the issue of just compensation. Several commonwealth countries, including the USA and UK, have legislations that require 'just compensation' as a prerequisite for expropriation. The term has led to an extensive debate and jurisprudence on the meaning of just compensation, and has led to different standards across countries (Luijt et al. 2003; Denyer-Green 2013).

The main justification for public land acquisition is the common or public good. There is a widespread admission for governmental land acquisition and expropriation in order to realise public goals under the condition of a 'just compensation' for the expropriated landowner (Denyer-Green 2013). Despite the widespread social acceptance of land acquisition, it can in practise lead to perceptions of injustice among landowners. Studies have shown that considering feelings of (in)justice is indeed important in understanding landowners' behaviour during land acquisition (Guo 2001; Holtslag-Broekhof et al. 2014). Guo (2001) studied the social and economic background of protest during the expropriation of land in rural China and found that the combination of low financial compensation and feelings of moral injustice made landowners protest against governmental land expropriation. While government officials stated that their takings were legal and just, the landowners stated that the local governments' behaviour was illegal and felt that injustice had been done to them. Holtslag-Broekhof et al. (2014) found that feelings of injustice explained why certain landowners were willing to sell their land to the government and others were not. Cvetkovich and Earle (1994) argued that feelings of justice are constructed during planning processes and that public participation can play an important role in shaping landowners' perceptions of justice and in creating shared values and discourses.

Most authors who have studied land management, land acquisition or expropriation have done this from a legal perspective upon justice. The individual's perceptions of just land acquisition have been underexposed in these studies thus far. Kalbro and Lind (2007), for example, elaborate on the amount of just compensation in Sweden. Ding (2007) did the same in China. These studies show that in both countries, just compensation is aligned with the market value of the

\footnotetext{
${ }^{1}$ Just compensation is an important principle in several expropriation laws.
} 
land. They also show the difficulty of determining this value due to a lack of comparable land transactions. Chang (2009) argues that the just compensation value should include the market value plus a bonus that is based on the type of landowner and length of ownership, as this is most efficient. Fennell (2004) argues that the market value that is compensated during regulatory takings in the USA always has an uncompensated increment which consists of the amount by which the subjective value of the owner exceeds the market value of the property, the freedom of choice to sell the property at a moment chosen by the landowner him-/herself, and the chance to make a profit when selling the property.

Perceptions of justice in general have been extensively studied by behavioural economists and psychologists. These studies have shown that despite the universal concern for justice, perceptions of justice are shaped differently in each situation (Montada 2012). Each person involved in land acquisition processes can have personal and divergent ideas on what constitutes (in)just land acquisition. Just land acquisition is more likely to be developed on the basis of knowledge on the way people perceive the justice of land acquisition (Cvetkovich and Earle 1994). This brings up two relevant questions; firstly, what do landowners and land purchasers perceive as just land acquisition? Secondly, which values underlie their perceptions of just land acquisition? In this article, we aim to unravel the prevailing discourse on just land acquisition and its underlying values in order to add a new perspective to debates on just land acquisition.

The next section provides a conceptual frame on perceptions of (in)just land acquisition. Following this, the methods of the study are introduced, and the context of this study is described. This is followed by the results of an analysis of interview transcriptions and newspaper articles in which we interpreted landowners' and land purchasers' perceptions of justice. Finally, the relevance of the findings for the wider debate on land acquisition and planning are discussed and conclusions are drawn.

\section{Perceptions of (In)just Land Acquisition}

The following paragraph presents the conceptual framework that was used to analyse perceptions of injustice. Many meanings of justice exist at the same time. Each individual person may have his or her own perception of justice. Simultaneously, groups of people may develop similar perceptions of justice, shaped by their shared cultural values or experiences. We perceive these shared perceptions of justice as discourses on justice. Recognising and portraying these different perceptions of justice is essential in conflict situations that involve justice, including land management (Davy 1997; Hartmann and Spit 2015).

Equity theory makes a distinction between distributive and procedural justice (Goodwin and Ross 1992; Yim et al. 2003). Studies on justice perceptions often focus on distributive justice, while according to equity theory, differences in distributions are rarely capable of explaining perceptions of injustice. Procedural justice would derive from the completeness of information for the participant, the opportunity for the participant to add to this information, the extent to which the 
decision maker uses this information, and the extent to which the participants feel that they have influenced the end result (Goodwin and Ross 1992). In terms of land acquisition, this implies that justice not only depends on the outcomes, but also on the rules and processes through which land acquisition takes place.

Land acquisition is not usually something that landowners have been acquainted with all their life. Their perceptions of just land acquisition start to be shaped when they are first confronted with land acquisition. The same holds true for land purchasers who will often first encounter this issue during their education, or work as land purchaser. Past, present and future actions (both of ourselves and of others) influence our personal value systems and enable us to build expectations about others' behaviour (Greif 2014). This implies that justice perceptions will be influenced by expectations about the behaviour of others, which in turn have been influenced by the individual's experiences in relation to justice. We make a distinction between these two types of expectations, the former being expectations about how people should behave (normative expectations) and the latter being expectations about the way people will behave (predictive expectations; Yim et al. 2003). For some actions, these expectations will correspond with each other, while in other cases they might conflict. For example, in most countries, car drivers expect that other road users will drive on the right side of the road and simultaneously think that other road users should drive at the right side of the road. The first predictive expectation follows from someone's prior experiences with driving, perceiving that all road users drive on the right side of the road, while the second normative expectation may stem from the traffic rules that this person has learned. The same person might however expect that road users should adhere to the speed limit, while simultaneously expecting that some road users will exceed the speed limit. In the last example the normative and predictive expectations do not correspond with each other, which may lead to negative feelings or indifference.

Behavioural economists found several patterns of human behaviour that might be relevant for understanding individual perceptions of just land acquisition. The first of the relevant concepts is 'loss aversion'. Loss aversion is the observation that people value losses twice as much as they value gains of an equal amount, during economic decisions (Tversky and Kahneman 1991). This is closely related to the 'endowment effect', whereby people become attached to property immediately after receiving it, causing loss aversion when they are forced to sell their property (Thaler 1980). This may cause people to attach more weight to their loss of land than the compensation fee that they receive in return, which may in turn lead to differences in perceptions of just compensation between the landowner and land purchaser. The second concept that may be relevant for the interpretation of just land acquisition is 'reference dependency'. Reference dependency is the tendency to value the outcomes of an economic decision in terms of losses and gains, instead of absolute values. In other words, people tend to refer the outcome in accordance with a set point of reference, such as the status quo (Kahneman and Tversky 1979). This may cause people to refer the expected outcome of the acquisition to their own or others' current situation.

The processes in which peoples' individual perceptions of just land acquisition are shaped and reshaped cannot be isolated from the more stabilised values of 
justice that people have formed throughout their life. Moreover, it is important to know the wider institutional context in which land acquisition takes place, including the planning and policy processes in which it is embedded and the social networks individuals are part of (Van Assche 2007). Perceptions of just land acquisition are shaped in various levels of social systems such as society, culture, family, working environment and in a person's values (North 2005; Ostrom 2005). All these systems may have their own written or unwritten rules and norms about expected behaviour (Ostrom 2005).

Figure 1 summarises the previous text by visualising the way in which the different elements that shape someone's perceived justice relate to each other. The figure shows that both rules and personal experiences lead to predictive and normative expectations on land acquisition. Cultural values and the biophysical world each influence the rules, expectations and perceptions of land acquisition. Rules and norms are influenced by personal experiences from social systems, including someone's personal 'system'. The difference between these expectations and someone's perceptions of the actual land acquisition determines his or her perception of the justice of land acquisition. If people's normative and predictive expectations and their actual perceptions correspond, they will perceive the acquisition as just. However, if their expectations and actual perceptions do not correspond, the experience of the acquisition should either make them adapt their prior expectations, or they will perceive the land acquisition as unjust. In practise, the perception of land acquisition is a personal experience that adds to other experiences that people have had in the past. In this way it may lead to new normative and predictive expectations about the rules, process and outcome of land acquisition. In other words, perceptions are dynamic and may change over time. In this study, we therefore analyse the difference between the expectations towards just land acquisition and the perception of land acquisition, with the aim of better understanding perceptions of justice of both landowners and land purchasers. We did this in the last stage of the acquisition process in order to include the possible feedback loop in the normative and predictive expectations.

As presented above, Fig. 1 was used as an analytical frame for the analysis. It represents the way justice perceptions are shaped for individuals. The advice of Davy (1997) to focus on feelings of injustice was followed. He argued that it is much easier to perceive a personal victory as a just victory than a personal defeat as a just defeat.

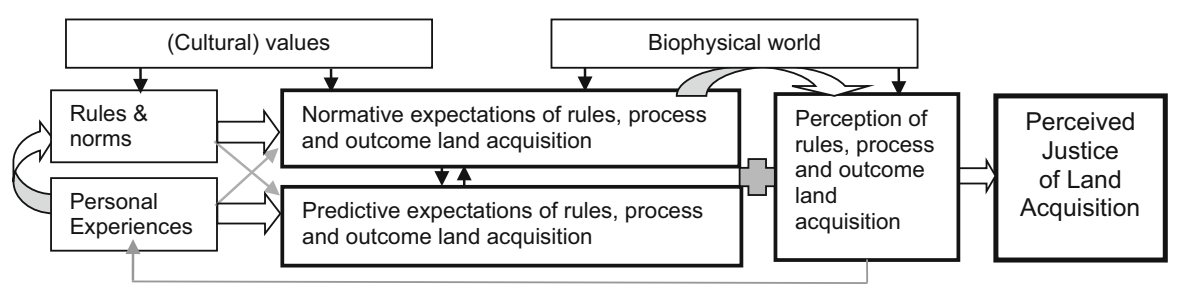

Fig. 1 The construction of perceived justice, adapted from Ostrom (2005) 


\section{Methods and Methodology}

As we are interested in different perceptions of just land acquisition, we analysed the interpretations of (just) land acquisition of the people involved in land transactions. We did this by conducting semi-structured interviews; interviews are suitable for an interpretative analysis as they allow us to analyse the original language in which people express their feelings (Wagenaar 2014). We decided to reduce the people involved in land transactions down to the two parties most centrally involved in acquisition: the land purchasers $(n=20)$ and landowners $(\mathrm{n}=20)$. The land purchasers were employed in various governmental and commercial institutions and were interviewed on their own considerations and frame with which they conduct land acquisition and their behaviour during land acquisition. The landowners were all involved with governmental plans on their property resulting in either the voluntary or involuntary sale of their property, or the wish to be bought out by the government while the government was not willing to buy their land. We did not directly ask about people's perceptions of justice in order to be as unobtrusive as possible and to prevent putting words in the participants' mouths. The questions asked were open and gave the interviewees the opportunity to describe their own perceptions of and views on the land acquisition and planning process. We recorded and transcribed all interviews.

We analysed interview transcriptions with Dutch land purchasers and landowners. To reveal different values that shaped landowners' and land purchasers' perceptions of justice, we systematically coded the transcriptions in two rounds. In the first round, we identified characteristic concepts and descriptions that related to the way people perceived the acquisitions process and its outcomes. This led to a list of 132 codes. This list was then used to code the second round consistently, during which we focused on the role of justice and the underlying values that were used by landowners or land purchasers to legitimise, explain or support their perception of (un)just land acquisition. Finally, we focussed on the codes that were related to justice and conducted a cluster analysis in which we focused on concepts that were named by the interviewees in coherence with justice-related terms. In the analysis we unravelled the different elements that determined peoples' justice constructions, how they related, and whether they differed between landowners and land purchasers.

In addition, we analysed news items that were related to expropriation and in which specific cases of landowners who had been expropriated or wanted to be expropriated were described. This led to 42 publications on expropriation reported in newspaper articles, journal articles, news items on television, as part of a professional research report, or as a television documentary. We used these cases to verify and strengthen the themes that we found in the prior analysis.

The interpretative method which was employed implies that the outcomes of this research are interpretations of interpretations. This means that the outcomes of such research are inevitably influenced by our own ideas of just land acquisition. 


\section{Context of the Study: Land Acquisition in the Netherlands}

This study was conducted in the Netherlands. The Netherlands is a densely populated country with 16.9 million inhabitants spread over $41,543 \mathrm{~km}^{2}$. This causes high pressure on land and a clear demand for public planning and land acquisition. Local governments have a broad set of instruments that they can use to conduct active land policy. The use of these instruments is accepted for planning tasks for which private property rights are regarded as inferior to the public good. Next to the option to purchase land sold voluntarily by landowners, governments have three major options to acquire private land. First, governments may cooperate with private landowners during the implementation of their plans and lawfully settle the costs of a certain development hand in hand with developing landowners ('grondexploitatie') Second, governments can claim a first right of purchase by laying a pre-emption right on land they want to develop in the near future. This is only possible if there is a land use plan. The pre-emption right has a validity of 3 years. If the landowner wants to sell his or her property during this period, he or she is obliged to offer the land to the government, which will pay the market value of the land. Third, and the most important to understand in the context of this study, is the expropriation law. This law allows governments to expropriate private property for the public good. Apart from a land use plan indicating the use that the government needs to expropriate the land for, there are three important conditions that governments need to meet in order to expropriate land from private landowners:

- The government has negotiated sufficiently with the landowner to buy the property on a voluntary basis.

- During these negotiations, the government offered the landowner a full compensation fee. This full compensation fee comprises the market value of the property, compensation for the loss in income, and other financial damage that the landowner has because of the expropriation.

- The landowner is not capable of realising the indented land use plan him-/ herself.

The judicial expropriation of landowners is only seldom necessary; most purchases are resolved before the actual lawsuit of expropriation, because the threat of expropriation is sufficient to make landowners sell 'voluntarily' (Buitelaar et al. 2007; Van Straalen and Korthals Altes 2014). The explanations of the public good, in the name of which governments are allowed to use expropriation, are registered in 11 legal titles for expropriation. These titles include for example a title for new road infrastructure, public housing, and a title for land consolidation. However, in practise the use of expropriation is not limited by the presence of titles, but by the political opinion on the public goals that are important enough to use expropriation. This has caused regional differences in terms of the ease with which expropriation is used, especially for nature conservation and recreation development purposes, while the use of expropriation for infrastructure development has been accepted throughout the past decades and is used consistently throughout the entire country. 
The Netherlands can be seen as an extraordinary case within expropriation legislations, as the indemnification of landowners is generous compared to expropriation laws in other countries. This makes it an interesting context in which to study perceived justice of land acquisition.

\section{Results}

The interviews and document analysis showed that (in)justice and related values were an important topic for the interviewees when talking about land acquisition. Especially in those situations where landowners were dissatisfied, the interviewees brought up perceived injustice spontaneously. In the newspaper articles, the group of landowners that were dissatisfied was overexposed. Just as the landowners indicated their dissatisfaction during the interview, the newspaper articles indicated perceptions of injustice due to indecent treatment, unequal treatment or both. Furthermore, land purchasers regularly emphasised the importance of a just outcome.

To further understand the results, the underlying values were analysed. Three underlying values were found to shape landowners' and land purchasers' norms of just land acquisition.

\section{Lawful treatment}

2. Decent treatment

3. Equal treatment

These values are related to the three aspects of land acquisition: the legal rules that enable and coordinate land acquisition (lawful treatment), the negotiation process between the government and landowner (decent treatment), and the outcome of land acquisition (equal treatment). The first value was brought up mainly by land purchasers. The second value was mentioned by both land purchasers and landowners. The third value was shared by both land purchasers and landowners, but mainly brought up by landowners.

In this paragraph, each of the values are described and elaborated upon in the normative expectations about land acquisition that follow from these values.

\section{Lawful Treatment}

Governmental land purchasers formed a small group of professionals that were educated to appraise and acquire real estate according to the Dutch law. It was important for them to ensure a just process of land acquisition. The main guideline that land purchasers used to ensure such a just process was the expropriation law. For most land purchasers, the law guaranteed that all landowners were treated lawfully (and therewith also equally) and received a full compensation, based on the market value of the expropriated property. The following quote is illustrative of the role which the expropriation law has in order to guarantee a just process according to land purchasers: 
At a certain moment you need a good frame for this job, because, if you went beyond the frame, something that is compensated with 10 Euros for one person and 15 Euros for another person and somewhere else for 100 Euros, then there is no logical line in your work anymore. (Land Purchaser)

To compensate landowners with the right price according to the standards of the expropriation law was of central importance for land purchasers. In line with Dutch legislation, the amount of compensation equals the market value of the property. In the case of expropriation, according to the Dutch expropriation law, the market values should be replenished with compensation for other financial damages a landowner suffers. Land purchasers described that the market value is estimated by official appraisers, so that it $i$ s the actual objective market value. The expropriation law provides guidelines for the indemnification of landowners. Indemnification is the principle that a landowner should be put back into the same economical position he or she was in before expropriation. In other words, the landowner should make neither a loss, nor a profit from the expropriation. This principle of indemnification is perceived by the purchasers as the most just manner of public land acquisition.

The expropriation law provided not only clear guidelines for a just outcome, but also the opportunity to settle an unsolved negotiation by employing an objective lawyer. The following land purchaser described this as follows:

Then it is very reasonable to go to court and to ask the judge to decide how much the compensation fee should be. So it is justified for those who have already sold their land and it is also justified for those who have not yet agreed to sell. We do not come to an agreement together, so let an independent third person decide what it should be. (Land Purchaser)

In this land purchaser's perception of just acquisition, the compensation is just if it is determined by an independent judge.

For land purchasers, the expropriation law offered an important guideline and instrument to treat all landowners equally (5.3) and to indemnify them in a structured manner. Land purchasers' perceptions of justice were clearly shaped by this law and its background and their past working experiences of successfully using the law.

The legislation was not used by landowners to legitimise their perceptions of the process. When it was named by landowners, they referred to the legislation as an absolute known fact that they were not able to influence, but that sometimes did not correspond to their own standard of a just land acquisition process.

\section{Decent Treatment}

The way the negotiation process of land acquisition is executed was named as an important requisite for just land acquisition by both landowners and land purchasers. Land purchasers emphasised the importance of gaining the landowners' trust during the acquisition negotiations. To this end, land purchasers stated that they should be empathic, open, unambiguous, good communicators, sociable, professional, accurate, sincere, and upright. Land purchasers named that it is important to serve not 
only the interest of the government during the negotiation, but to also serve the interest of the landowner. All land purchasers were of the opinion that an empathic and open attitude was important to gain the landowners' trust and to be able to buy the land. However, motivations to act openly and empathically differed amongst land purchasers. Some described their motivation for this behaviour by explaining that they felt it was a moral duty to act decently, while others simply felt that such behaviour helped them to reach their goal of purchasing the land. Despite the good intentions and empathic skills of most land purchasers, many landowners had negative impressions of the spatial planners, politicians and other governmental officials whom they had met during the land acquisition process. A specific attitude or a misplaced remark of a planner or politician could shape the landowners' view of the acquisition process. According to the land purchasers, most planners are insufficiently aware of the impact of land acquisition on landowners and the importance of being open and empathic towards all landowners.

The lack of information, clarity and openness about the plans in the first stages of the planning process was named as undesirable by landowners.

Yes, just information, that they are open. Look, they really cannot scare us or so, but then we can give our opinion about the plans and then people can also make up their mind about it, like if people really want to move from their place or some people do not want to move. (Apartment owner)

Apart from the obvious desire to be informed about your own environment and future, the desire for openness and transparency might also be related to the landowners' feeling of being taken seriously.

Apart from the sociability and accuracy of the process, the right amount of time is also a relevant issue, and one that was named by both landowners and land purchasers. Land purchasers named 2-3 years as a reasonable amount of time for a negation process for the acquisition. Land purchasers argued that this time is needed for landowners to get used to the idea that they will have to move and to search for an alternative location. Both landowners and land purchasers agreed that it is not good for the process to be too lengthy, as this leaves people in uncertainty for too long.

People are kept endlessly in the dark about what is going to happen, because it is not in their interest... so yes, unjust so eh if you have some sense of justice then these kinds of things are very difficult for you. Not only for yourself but also for others. (Landowner)

In some planning processes this uncertainty can even continue for more than 20 years. The following quote comes from a landowner who has already been in a situation of uncertainty about her house for more than 22 years:

For years, the uncertainty about the new highway and before that the new railroad has been determining the steps we make in our life.... We understand that the government's decisions bring along certain burdens for individual citizens and that is acceptable, but in our situation a line has been crossed... In 
this situation, the government is acting unjustly. As a citizen you should not be the victim of governmental decision making." (Landowner)

Land purchasers were well aware of landowners' negative feelings regarding long periods of uncertainty caused by long decision-making processes. One land purchaser described that the long lasting process could lead to situations that did not feel good for him, although he acted in a manner he regarded to be right.

Yes, we call that the longest breath of the government, we do everything in a fair manner, but it does not always feel good. You can offer such good compensation, but you can also see, yes you do see very lingering situations, also people that get all kinds of tensions in their family. (Land Purchaser)

The quote shows that this land purchaser's perception of justice is close to acting 'according to the rules', while his personal feeling simultaneously led him to feel that the government's persistent manner of acquisition was immoral.

Several landowners described feelings of injustice due to the difference between their own position and skills and the expertise and skills of land purchasers.

Then I think, oh that is so frustrating, they know exactly what regulations they have use and yes for us it is the first time and so yes, we do not know it yet, but it does makes me feel like yes they know how the game is played and eh that is just frustrating to suffer from that, yes that is how it feels. (Landowner)

Landowners described the feeling of having no choice and of being in an unequal power position compared to the government. Although they were able to negotiate over the conditions of selling, several felt that these negotiations were rather onesided. From their perspective, the government could do anything as long as it was according to the rules, even if these rules do not indisputably guarantee a just process. The following two quotes illustrate this.

You do not have so much choice. Look, we profited from the fact that we have two farms next to each other now. But at the moment that you are given the choice, we had to agree or not, yes we could have said no, but then we would not have had it of course. And I still think like we should have tried this or that, but yes we did not have another choice at that moment. Our hands were tied. (Landowner)

Not only was the government perceived as more powerful than the landowners, but the landowners also describe a difference in emotional involvement with the land between themselves and the government. While landowners experience a strong emotional involvement in the plans that can impact their social life and can have a strong impact on their personal well-being, they feel that the government professionals can end their work at five o' clock, and go home without worrying about the project.

Obviously, the perceptions of decent land acquisition differed amongst landowners. For example, the negotiation process itself was perceived as frustrating, unequal and unjust by some, while others said that they enjoyed the game of negotiating and trying to get the best out of it. However, the aspect of a decent 
process was mentioned by the vast majority of landowners and all of the land purchasers as being an important aspect of just land acquisition.

\section{Equal Treatment}

About half of all landowners and all of the land purchasers mentioned the importance of treating people equally. The owners and purchasers shared a value of equal treatment in equal situations, but this value translated into different norms for land purchasers and landowners. This paragraph deals with both the landowners' and land purchasers' perceptions of equal treatment.

In areas with multiple land use developments, land prices are likely to diverge. In particular, the difference between the amount paid for land for urban development and land that is bought for other purposes might differ significantly. For landowners living in such areas, these differences are not always understandable and are often perceived as unjust. Landowners used references to other people in order to ground their perceptions of injustice, stating that they were not treated equally with neighbouring landowners. The following quotes by landowners illustrate this.

Financially you do not profit from it at all. While other people who have to move for housing development, they are also located close to the city, they sell everything to project developers, they get ten times as much land as we get. (Landowner)

When you are a landowner in this country and you are in the way of housing development then you get very high compensation or you can sell your land for a lot of money....That is of course very strange because we all lose land and have to buy back land somewhere else. That mistake in thinking that is fully integrated in the Dutch polder model causes the failure of this kind of plans. (Landowner)

The idea that others would profit from the loss that the landowners were suffering strengthened the feeling of injustice among several landowners. Moreover, landowners described that the different acquisition fees that landowners in the same region received caused unequal competition on the land market. While six landowners referred to others to explain their own perception of injustice, only one of them mentioned that he had difficulties with the process because of the injustice and harm that was done to others.

Most land purchasers perceived the system of land valuation as just. At the same time they were also aware of the local differences in land values and often found it difficult to explain to landowners how the system works. Despite the overall positive ideas, some land purchasers did mention that the way the system of land valuation works may be unjust. This difference in perceptions of justice can be seen in the following two quotes from two land purchasers.

People whose land is acquired for housing developments, they have of course, yes they have coincidental luck, because there is coincidentally a pen stroke on their land that it will become residential land. I find that a little bit strange, in the legislation they might want to change that because if someone is 
disadvantaged from planning, planning damage, then they can claim for it, but if someone profits then you cannot take this. As a matter of fact, that would be more realistic. Because why would someone who is a farmer in an area that is coincidentally zoned for housing development become a millionaire? (Land Purchaser)

That is the difference and that, that is something that you cannot explain to people. No matter how fair we work, it never feels good for those people. (Land Purchaser)

The first land purchaser thought that the legislation could be changed because it led to inconsistent outcomes between different situations, while the second purchaser (talking about the same difference between the value of land that is zoned for urban use and the value of land that is zoned for natural use) perceived the approach as just, but found it hard to explain the system to landowners. Although the majority of the interviewed landowners did indeed have difficulties in accepting the differences in compensation fees for natural and urban development, several landowners did show an understanding of the system and did not use the concept of inequality to argue only for their own interests. These landowners showed an understanding of the fact that the government cannot easily give a higher price to them compared to others:

But okay, they have to stay with a realistic value as well, they cannot say like, that barn of yours is worth three times as much as the others because we like you and at the others we do not get coffee. (Landowner)

The reference to others was not only used in the situation of different land values, but was also used when landowners felt that another group was in any way privileged compared to them. This could for example lead to feelings of injustice among landowners whose land was not purchased by the government.

So they have had an acquisition policy for shop owners, then we said, well if you want to build that's fine, we would like to move anyway, we do not need the jackpot, but just buy us. But they don't do that. So then I thought, shop owners yes and owner-occupiers no, then it becomes crooked. (Apartment owner)

The reference to 'others' was even made by some landowners regarding the land use plan ('there is space for more water, but there is no space for us'). Several landowners referred to their own situation before the (future) selling of the land. This often resulted in feelings of satisfaction about their decision to sell their land. However, this could also result in the demand for a good solution (often a good new location) and the complaint that the compensation fee was not sufficiently able to help them get a new location.

We do not oppose expropriation in itself. If it is in the public interest, who are we to fight against that? But we do want another location or sufficient means to buy a location. We do not have to get rich from it, but we also do not want to get poorer. (Landowner) 
This quote also illustrates the feeling of many landowners who were expropriated for land use that was designated as public interest, such as road infrastructure. In return, the landowners expected to be supported in finding a good solution for their situation. Landowners who did not agree that the plan they were expropriated for was for in the public interest, such as nature development, were also more often negative about expropriation in itself.

Not all land acquisition is based on the principles of the expropriation law. Sometimes land is acquired on a voluntary basis, without full compensation but also without the possibility of expropriation. Several purchasers described acquisition without full compensation as unjust. This land purchaser for example stated:

It is not more than fair that we offer a full compensation fee, because you do not pay more, but you compensate for the financial damage people have. And so you do not offer them too much, but that is often the assumption, that you pay too much, or you pay more so that's why you can buy, but that is not the case, it is just the indemnification of people to the same financial position as before. (Land purchaser)

The decision to buy on the basis of the expropriation law is made by politicians who are often resistant to doing this for socially less accepted land uses.

Several land purchasers stated that it is unjust to not expropriate once you have started an acquisition process in a certain area. The following quote illustrates this:

That is what I always say to politicians, at a certain moment you do need to expropriate because if you don't, it is at least unfair to those who already agreed to sell. Then you would favour those who remain unwilling to sell for a long time and that is not desirable, because that is not just. (Land Purchaser)

The quote shows that this land purchaser attaches a lot of value to the equal treatment of landowners, which includes purchasing the land within a limited time frame.

The 'equal treatment' that landowners and land purchasers referred to seemed to be more a means towards an equal outcome than a goal in itself. When we examine the different perceptions of landowners and purchasers this way, their different expectations can be better understood. While for landowners a good outcome mainly meant a good new location, or a good solution to compensate the loss of land at their existing location, land purchasers focussed on the 'right' amount of money. In most cases this full compensation fee is sufficient and capable of allowing the landowner to 'buy a good solution'. However, in some cases the solution that a landowner needed was so specific or difficult to achieve that the compensation fee was no solution to their problem. In these cases, it was especially essential for the land purchaser to be understanding and helpful towards the landowner's problem and to allow the landowner time to arrange this solution. When this did not happen-according to the perceptions of the landowner-perceptions of an unjust process or outcome were present. 


\section{Discussion}

Perceptions of just land acquisition by both landowners and land purchasers were studied. The fact that these strongly diverge is in itself not a surprising outcome. These perceptions, however, revolved around three core values. Almost all landowners and land purchasers confirmed the need for expropriation in order to realise public purposes. The different discourses on just acquisition therefore did not differ in terms of the justice of the fundamental principle of expropriating landowners for public interest, but differed instead in their perception of what entails a just process and outcome of land acquisition.

The study showed the importance of the land acquisition process for people's perception of just land acquisition. This adds to the existing literature that mainly focusses on just outcomes of land acquisition (Levmore 1989; Deutsch 2005; Kanner 2011; Parke 2012; Zhang 2013). Given the differences in expropriation legislations and the often low compensation fees that landowners receive, this is not surprising. The importance of the process is confirmed by equity theory that also makes a distinction between distributive and procedural justice (Goodwin and Ross 1992; Yim et al. 2003). The aspects of procedural justice that Goodwin and Ross (1992) distinguish proved indeed to be of importance for the landowners' feelings of injustice; in particular, the feeling of having an influence on the outcome added to their perceptions of a (un)just process. The outcome also corresponds with the findings of Cvetkovich and Earl (1994) that endorse the importance of a just process during land management.

The empirical results for this study were collected in the Netherlands. In the Netherlands, the framework of the Dutch expropriation law is clear and has extensive jurisprudence on just compensation. This is comparable to the situation in most developed countries. Moreover, the values that were found as basis for landowners and land purchasers are broadly shared values across developed countries. It is therefore probable that comparable results will be found if this study would be repeated in other developed countries.

Landowners generally have normative expectations about the process and outcome of land acquisition, as it is not something that they face on regular basis, while land purchasers also had predictive expectations about the process and outcome of land acquisition. The presence of predictive expectations may be an important explanation for the different interpretations of just land acquisition between landowners and land purchasers.

Reference dependency (Tversky and Kahneman 1991) was indeed found to help understand the way landowners valued and judged the outcome of the acquisition process. However, loss aversion (Tversky and Kahneman 1991) was not useful in helping to understand landowners' perceptions of injustice. This was largely inherent to the research design.

Attempts to fully catch a 'fair and equitable' process in our expropriation legislation may have failed, and will continue to fail, as a full meaning of fair and equitable is more than we can prescribe by the expropriation law. During the 150 years that the expropriation legislation exists in the Netherlands, it has been 
detailed by several sentences Law Lords, that increasingly include regulation for a just compensation fee in specific circumstances. There is an enormous faith in the role of this law in safeguarding a just process amongst professional land purchasers. However, professionals might hand over too much responsibility to the law alone, while perceptions of justice are not experienced through legislative drafting, but through actual experiences of human interaction.

As Davy (1997) has already concluded, feelings of injustice during planning are and will remain inevitable. This does however not imply that we can neglect the theme and remain loyal to current planning practises without critically evaluating these. It does imply that we might adjust the impossible aim of 'justice for all' to 'enough justice for all' (Davy 1997).

During justice decisions, "whatever a planner decides for herself, she has to be aware that others who have different values will take issue with her decision. The planner must explain her concept of justice to them. If she is not able to communicate about justice, but hides behind the principle of efficiency, she alienates stakeholders who maybe obstruct her plans' (Davy 1997)

\section{Conclusions}

This paper studies the different perceptions of (un)just land acquisition and their underlying values among land purchasers and landowners. It shows that these perceptions are hugely divergent, but revolve around three important values: lawful, decent, and equal treatment. These values translate into different norms pertaining to just land acquisition. The study moreover showed that for both landowners and land purchasers, just land acquisition entails much more than simply a just compensation fee. Current studies emphasise the level of the compensation fee, rather than procedural and interaction aspects of the acquisition process (Fennell 2004, 2013; Kalbro and Lind, 2007; Kanner 2011; Parke 2012).

Land purchasers used values of lawful, decent, and equal treatment to legitimise their perceptions of just land acquisition, while landowners only used values of decent and equal treatment to legitimise their perceptions of just land acquisition. Land purchasers and landowners had different ideas about 'equal treatment'. Land purchasers perceived equal treatment as ensuring that all landowners receive the right amount of financial compensation according to the principles of the expropriation law. For landowners, it was more important to have a solution for their own situation and the feeling to have gained as much (or more) as others. Most land purchasers were aware of this, while planners and policy makers often lack this awareness.

Despite the international differences in the design of expropriation legislation, the basis of acquisition and expropriation processes is remarkably comparable. Hence it is likely that similar results would be found in other developed countries if perceptions of just land acquisition were to be studied.

Uncovering different perceptions of just land acquisition and their underlying values improves the understanding of land acquisition processes and land policy strategies. First, it shows that land acquisition has an essential injustice that we will 
have to accept and that cannot be avoided by a good process or a just compensation fee. Second, it shows that the different discourses are a valuable input to the debate of just land acquisition. They show that we should not be so afraid to expropriate per se, as long as we can clearly communicate the importance of the public purpose that we expropriate for, take enough time to organise an accurate and open process in which the interests of landowners are taken seriously, and ensure an outcome in which the landowner is truly brought back in the same economic position as before the transaction. Third, it shows that money is not always a sufficient means to indemnification. Reasons that landowners gave to be satisfied with their sale of land to the government were barely related to the amount of money they received, but to the conditions of selling and possibility to improve in the new situation (for example to gain full ownership of their arable land or to increase the size of their farmland).

Just compensation for expropriation has been studied extensively in the literature. However, this study shows that just expropriation encompasses more than just compensation. The accurate, open and sociable way of coming to this compensation fee is an equally important requisite for just land acquisition as the compensation fee itself. This does of course not mean that an accurate, open and sociable process will compensate for a compensation fee that is perceived as too low to cover the landowners' value and costs. The combination of sufficient financial compensation, a new location, attractive selling conditions and an accurate and open process are all important requisites for ensuring that land acquisition will be perceived by the majority of landowners as just.

Open Access This article is distributed under the terms of the Creative Commons Attribution 4.0 International License (http://creativecommons.org/licenses/by/4.0/), which permits unrestricted use, distribution, and reproduction in any medium, provided you give appropriate credit to the original author(s) and the source, provide a link to the Creative Commons license, and indicate if changes were made.

\section{References}

Buitelaar, E., Lagendijk, A., \& Jacobs, W. (2007). A theory of institutional change: Illustrated by Dutch city-provinces and Dutch land policy. Environment and Planning. A, 39(4), 891.

Chang, Y-C. (2009). Economic value or fair market value. In The efficient standard of physical takings compensation. Law and Economics Research Paper Series Working Paper (1477670).

Cvetkovich, G., \& Earle, T. C. (1994). The construction of justice: A case study of public participation in land management. Journal of Social Issues, 50(3), 161-178.

Davy, B. (1997). Essential injustice: When legal institutions cannot resolve environmental and land use disputes Vienna. New-York: Springer.

Denyer-Green, B. (2013). Compulsory purchase and compensation. London: Taylor \& Francis.

Deutsch, U. (2005). Expropriation without compensation-the European Court of Human Rights Sanctions German Legislation Expropriating the Heirs of New Farmers. German LJ, 6, 1367.

Ding, C. (2007). Policy and praxis of land acquisition in China. Land Use policy, 24(1), 1-13.

Fennell, L. A. (2004). Taking eminent domain apart. Michigan State Law Review, 2004, 957-1004.

Fennell, L. A. (2013). Just enough. Columbia Law Review Sidebar, 113, 109-122.

Goodwin, C., \& Ross, I. (1992). Consumer responses to service failures: Influence of procedural and interactional fairness perceptions. Journal of Business Research, 25(2), 149-163.

Greif, A. (2014). Do institutions evolve? Journal of Bioeconomics, 16(1), 53-60.

Guo, X. (2001). Land expropriation and rural conflicts in China. The China Quarterly, 166, 422-439.

Hartmann, T., \& Spit, T. (2015). Dilemmas of involvement in land management-Comparing an active (Dutch) and a passive (German) approach. Land Use Policy, 42, 729-737. 
Holtslag-Broekhof, S., Beunen, R., van Marwijk, R., \& Wiskerke, J. (2014). "Let's try to get the best out of it" understanding land transactions during land use change. Land Use Policy, 41, 561-570.

Kahneman, D., \& Tversky, A. (1979). Prospect theory: An analysis of decision under risk. Econometrica: Journal of the Econometric Society, 47(2), 263-291.

Kalbro, T., \& Lind, H. (2007). Compulsory purchase-reasonable and fair compensation. Nordic Journal of Surveying and Real Estate Research, 4, 1.

Kanner, G. (2011). Fairness and equity, or judicial bait-and-switch-it's time to reform the law of just compensation. Alb. Gov't L. Rev., 4, 38.

Larbi, W. O., Antwi, A., \& Olomolaiye, P. (2004). Compulsory land acquisition in Ghana-Policy and praxis. Land Use Policy, 21(2), 115-127.

Levmore, S. (1989). Just compensation and just politics. Connecticut Law Review, 22, 285.

Luijt, J., Veeneklaas, F. R., Schans, J. W., \& Venema, G. S. (2003). Ontvlechting van de productiewaarde en optiewaarde van landbouwgronden; Oplossingsrichtingen van Denktank Melkveehouderij. (Vol. Rapport 4.03.01). Den Haag: LEI.

Montada, L. (2012). The normative impact of empirical justice research. Berlin: Springer.

Morris, S. (2007). Towards reform of the land acquisition framework in India. Indian Institute of Management Working Paper (2007-05), 04.

Moyo, S. (2000). The political economy of land acquisition and redistribution in Zimbabwe, 1990-1999. Journal of Southern African Studies, 26(1), 5-28.

North, D. C. (2005). Understanding the process of economic change. Princeton, NJ: Princeton University Press.

Ostrom, E. (2005). Understanding institutional diversity. Princeton, NJ: Princeton University Press.

Parke, N. (2012). How much is fair? Will Senate Bill 18 ensure condemnors pay just compensation for land taken due to the CREZ transmission lines? Texas Tech Law Review, 44, 1-43.

Sarkar, A. (2007, April 21). Development and displacement: Land acquisition in West Bengal. Economic and Political Weekly, 1435-1442.

Thaler, R. (1980). Toward a positive theory of consumer choice. Journal of Economic Behavior and Organization, 1(1), 39-60.

Tversky, A., \& Kahneman, D. (1991). Loss aversion in riskless choice: A reference-dependent model. The Quarterly Journal of Economics, 106(4), 1039-1061.

Van Assche, K. (2007). Planning as/and/in context: Towards a new analysis of context in interactive planning. METU JFA, 2(24), 2.

Van Straalen, F., \& Korthals Altes, W. (2014). Compulsory purchase for biodiversity conservation in the Netherlands. Land Use Policy, 38, 223-232.

Wagenaar, H. (2014). Meaning in action: interpretation and dialogue in policy analysis. London: Routledge.

Yim, C. K., Gu, F. F., Chan, K. W., \& Tse, D. K. (2003). Justice-based service recovery expectations: Measurement and antecedents. Journal of Consumer Satisfaction Dissatisfaction and Complaining Behavior, 16, 36-52.

Zhang, X. (2013). Seeking just compensation for collective-owned land expropriation in China. SSRN 2331225 . 